\title{
The Role of Marine and CoAstal PRotected AREAS IN THE CONSERVATION and Sustainable Use of Biological DIVERSITY
}

By W.M. Eichbaum, M.P. Crosby, M.T. Agardy and S.A. Laskin

In the absence of a true, functional globally integrated network of MACPAs that is essential for the comprehensive conservation and sustainable use of marine biodiversity, there is a critical lack of integration between and even within many of these programs.

\begin{abstract}
A ment have never seemed greater, the importance of marine biological diversity and its conservation have never been more clear. While the traditional measure of biological richness as species diversity has kept terrestrial ecosystems at the forefront of discussions in conservation biology, new perspectives of biodiversity that use higher taxa highlight the great diversity of marine biota. Unique forms of marine life, such as deep-sea hydrothermal vent communities, continue to be discovered in the marine environment. A diversity of marine organisms enhances critical ecosystems functions, such as sequestering atmospheric carbon and protecting coastal areas from storm processes. Although global marine productivity is patchy, productivity rivals that of terrestrial ecosystems in many places with gross productivity in coral reef and estuarine ecosystems reaching $20 \mathrm{~g}$ of carbon per square meter per day. The great diversity of marine organisms form the foundation that enables human communities to sustainably utilize marine resources for animal protein (up to 50\% of total animal protein intake in some areas), sources of anti viral and anti tumor medicines, and raw materials used in agriculture and other activities.

An increasingly important mechanism to advance the protection of marine biodiversity is the new generation of marine and coastal protected areas (MACPAs). Today's MACPAs have evolved considerably from the traditional model of the ter-
\end{abstract}

W.M. Eichbaum, M.T. Agardy and S.A. Laskin, World Wildlife Fund, 1250 24th Street, N.W., Washington, DC 20037. USA. M.P. Croshy, Office of Ocean and Coastal Resource Management, National Oceanic and Atmospheric Administration, 1305 East West Highway, Silver Spring. MD 20910, USA. All correspondence should be directed to M.P. Crosby. This manuscript reflects the opinions of the authors and is not meant to represent the official policy of any government agency. restrial park and can achieve far more than the protection of critical habitats and endangered species. Additional important niches that modern MACPAs fill are public education and outreach, as well as serving as a physical reminder of the social, economic, and ecological benefits of marine and coastal resource protection. By employing a framework for the application of "adaptive management." MACPAs can establish and maintain feedback loops between science and policy. Finally, multiple-use MACPAs address the differing sets of objectives of a myriad of stakeholders, thereby providing a framework for resolving conflict between various users of marine and coastal ecosystem services.

Several international, national, and state/local level mechanisms exist that serve to advance the management objectives of MACPAs. In the international sphere these include the Man and the Biosphere program, the World Conservation Union (IUCN), the Biodiversity Convention, the Regional Seas program, and IMO Sensitive Sea Areas. In the United States, such mechanisms exist in NOAA's Marine Sanctuaries and National Estuarine Research Reserve System programs, and the National Park Service's marine and coastal parks. In the absence of a true, functional globally integrated network of MACPAs that is essential for the comprehensive conservation and sustainable use of marine biodiversity, there is a critical lack of integration between and even within many of these programs. The challenge now facing the world is to integrate these programs into a true and robust system for conserving marine and coastal biological diversity.

\section{Introduction}

The overall health of the marine environment is deteriorating as a result of a variety of anthropogenic activities on land and sea (Norse. 1993). There are currently over 110 million $(\sim 50 \%)$ of the United States and 70\% of the world's popula- 
tion living within the coastal zone (Culliton et al., 1990; Sobel. 1993). By the year 2010, the U.S. coastal population is predicted to be $>127$ million (Culliton et al.. 1990). Some of the greatest threats to the resiliency and sustainable use of marine and coastal biodiversity are the over exploitation of living marine resources, the degradation of coastal habitats, nonpoint source pollution, and the anthropogenic introduction of alien species (most commonly in ship ballast waters) (Bjergo et al., 1995). All of these actions can individually and through synergy alter finely tuned ecological relationships that directly and indirectly lead to loss of biodiversity at the genetic, species, and habitat levels. Another factor contributing to current marine ecosystem degradation is the release of manmade materials into ocean and coastal areas, either as wastes or as a by-product of the use of materials such as petroleum or pesticides. And although efforts are being made to address these threats, there is growing evidence that future stresses on marine resources from global environmental change will be significant, constraining the options for human use and limiting the resiliency of the natural system (Norse, 1993).

The term biological diversity as used in the Convention on Biological Diversity means ". . . the variability among living organisms from all sources including. inter alia, terrestrial, marine and other aquatic ecosystems. . . Roughly $68 \%$ of the earth"s surface is in oceans and seas (Davis. 1973), and marine life exists throughout this continuum from the surface layer to the deep-sea floor. But because of physical limitations to ocean exploration at extreme depths $(>9,000 \mathrm{~m}$ in places). scientists have only been able to sample a fraction of the deep sea and can currently only estimate total marine species diversity. The three-dimensional nature of the ocean space and the fact that the major part of that space is beyond direct observation require a fundamentally different approach to studies of biological diversity in the marine environment than in the terrestrial environment. Furthermore, marine organisms are strongly dependent on the physical and chemical components of the environment, and studies of marine species diversity must therefore be integrated in oceanographic studies.

The extent of biodiversity reduction in the marine environment is insufficiently known. As of May, 1995, 1,406,138 species of marine organisms (1,077.508 metazoans, 318.880 plants. fungi and protists, 4,750 prokaryotes, and 5.000 viruses) were identified by the UNESCO Register of Marine Organisms. However, Grassle and Maciolek (1992) have estimated that the deep-sea alone may harbor $10,000,000$ species that have not yet been described and named. Although the traditional measure of biological richness as "species diversity" have dominated biodiversity discussion in terrestrial ecosystems, different perspectives of biodiversity that use higher taxa highlight the abundant diversity of marine biota. Indeed, of 33 known animal phyla, 32 exist in marine ecosystems, and 15 of these are endemic (Norse, 1993). In comparison, only one animal phylum is endemic to terrestrial ecosystems.

\section{The Value of Marine Biodiversity}

Unique forms of marine life are continually identified. In 1938 scientists discovered a group of fishes that were thought to have become extinct $70-80$ million years ago. These fishes are a close relative of the ancestor of amphibians, reptiles, birds, and mammals, and the identification of one species was considered the biological discovery of the century (Thomson. 1991). The 33rd animal phylum, Loricifera-microscopic animals that live between grains of sand in the sea floor-was only identified in 1983. Since then, this phylum has been found to have an almost global range, existing in the Gulf of Mexico, the Mediterranean Sea. and the Pacific Ocean (Weber and Gradwohl, 1995). In 1977 the first animal community not to depend on plant photosynthesis for energy was discovered near deep-sea hydrothermal vents off the Galapagos Islands (Norse. 1993). Instead of obtaining energy from the sun, invertebrates and fishes that live near the vents derive energy from mutualist bacteria that make carbon via chemosynthesis. Similar animal communities have been found at thermal vent sites in the Atlantic and Pacific oceans since this discovery (Norse. 1993). Endemism is high in vent communities; 223 of 236 species identified at vent sites, belonging to $>100$ new genera and 22 new families, are new to science (Tunnicliffe. 1991).

The diversity of the marine environment extends to the ecosystem level as well, with oceans and coasts providing a wealth of habitat types from salt marsh estuaries, mangrove ecosystems, and coral reefs, to seagrass beds, kelp forests, upwelling areas, and deep sea floors (Davis. 1973; Odum et al., 1976: Agardy, 1994). Coastal wetlands provide nursery habitat for many species. In addition to providing habitat for terrestrial animals, mangrove forests trap sediments and prevent erosion, thereby protecting coral reefs from damaging siltation. Coral reefs are one of the most biologically diverse and productive natural ecosystems in the marine environment. They are vital to the ecological sustainability and to the economies of coastal regions. Coral reef ecosystems, and associated mangroves and seagrass beds, provide sheltered waters and high productivity that have long attracted human settlement. Hence coral reef ecosystems support not only tremendous biodiversity but are also the basis of significant economic and cultural activities through fisheries and tourism and often form the centerpieces for subsistence and spiritual linkages of indigenous peoples in the United States and around the world (Crosby and Maragos, 1995).

\section{Some of the great-}

est threats to the

resiliency and sus-

tainable use of

marine and coastal

biodiversity are the

over exploitation of

living marine

resources, the degra-

dation of coastal

habitats, nonpoint

source pollution, and

the anthropogenic

introduction of alien

species. 
The inherent biodiversity of marine ecosystems has historically provided for the sustainability of many coastal zones and islands human communities. Marine animals are an important global food source, with up to $50 \%$ of total animal protein intake derived from the sea in some countries (Norse, 1993). From marine biota such as red algae, chinook salmon, horseshoe crabs, basking sharks, sea urchins, and squid, humans derive a wealth of medicinal and cosmetic products (Weber and Gradwohl, 1995). Ara-A, an anti viral compound, and Ara-C, a compound used to fight leukemia, were derived from chemicals present in marine sponges (Norse, 1993; Weber and Gradwohl, 1995). Similarly, research indicates that skeletons of stony coral have potential use in human bone grafts (Weber and Gradwohl, 1995). In many coastal agricultural areas, seaweeds are used for livestock feed and soil fertilizer, while mangroves provide wood for construction and fuelwood and tannins for use in leather manufacturing (Norse, 1993). Finally, the importance of recreational opportunities and aesthetic values provided by marine ecosystems, both to local populations and in support of coastal ecotourism activities, cannot be overlooked.

Marine and coastal biodiversity is also important for the significant role it plays in global climate functions through processing and storing carbon. The oceans act as a reservoir for $75-80 \%$ of global carbon. Marine phytoplankton, which generally inhabit only the top 300 feet of ocean waters, account for $\sim 40 \%$ of global photosynthesis (Weber and Gradwohl, 1995). While global marine productivity is patchy, productivity rivals that of terrestrial ecosystems in many places (Agardy. 1994); gross productivity in coral reef and estuarine ecosystems can reach $20 \mathrm{~g}$ of carbon per square meter per day (Norse, 1993). Kelp beds are also highly productive, with the upper fronds of giant kelp able to grow up to 2 feet per day (Weber and Gradwohl. 1995). Areas with high phytoplankton productivity support a great diversity of marine, bird, and mammal life. For example, $>300$ species of coral, 1.500 species of fish, and 4,000 species of mollusks inhabit Australia's Great Barrier Reef (Weber and Gradwohl, 1995).

There are many opportunities for sustainable uses of marine and coastal ecosystem resources. However, growing demands and levels of conflict among competing uses are increasingly limiting the opportunities for full use of these resources while maintaining the basic biological diversity and ecological integrity of these ecosystems. In general, humankind has not yet grasped the concepts needed to manage relations between people and the oceans. In 1990, IUCN, UNEP, and the World Wide Fund for Nature challenged the governments and peoples of the world to redress this basic misunderstanding and develop suitable institutions and management mechanisms. The Inter- parliamentary Conference on the Global Environment (Washington, DC, May 2, 1990) concluded that short-term economic benefits from exploitation of ocean and water resources deprive future generation, diminish the quality of life, disrupt international stability and global security, and even threaten life itself; and that Nations should join together to protect marine biodiversity and productivity.

However, the fundamental goal of resource protection is subject to broad interpretation (Ray and McCormick-Ray, 1990). "Protection" may include a range of management strategies, policies and regulations from "strict" (limited or no use) to "multiple use." Ray and McCormick-Ray (1990) have questioned whether it is the purpose of natural resource management to 1) protect the resource, habitat, or ecosystem for human use and promote resource replenishment, or 2) maintain an ecosystem's natural productivity or diversity? They conclude that there is obviously no "rule of thumb" for management strategies, policies, and regulations that will assure resource protection in diverse marine ecosystems. One manifestation of the poor management of natural resources is the loss of biological diversity. The problem of biodiversity loss and ineffectual management of natural resources has many aspects: social, economic, cultural, managerial, and scientific (Solbrig. 1991).

\section{A Role for Marine and Coastal Protected Areas: Management for the Conservation and Sustainable Use of Biodiversity}

An increasingly important mechanism for promoting the sustainable use and conservation of marine and coastal biodiversity are the new generation of marine and coastal protected areas (MACPAs). Many of the more recently implemented MACPAs represent a decided departure from the rigid, limited marine management tools of the past and their previously strong links to terrestrial park planning (Agardy, 1994). MACPAs are no longer thought of as amusement parks for an elite group of users. Rather, they are beginning to be viewed as a mechanism for addressing a wide range of marine resource and ocean space management dilemmas. Indeed, well-planned MACPAs can achieve far more than the protection of critical habitats and marine biodiversity. The new generation of MACPAs (i.e., Florida Keys National Marine Sanctuary) are largely represented by multiple-use reserves with management plans that accommodate many different users and stakeholders (NOAA, 1995). MACPA managers are finding that different interest groups can be accommodated, and multiple uses can indeed be fostered without adverse impacts on ecosystem function and biodiversity, as long as the MACPA management strategy is based on ecological and socioeconomic realities with specific management objectives agreed upon from the outset. This is the 
approach NOAA is attempting to employ in the National Marine Sanctuary Program.

For the purposes of this discussion, MACPAs may be thought of as areas of the coastal zone or open ocean (or both) that are the target of management for the broad purpose of conservation and sustainable use. In this sense, MACPAs constitute a broad spectrum of coastal and marine areas that are afforded some level of protection for the purpose of managing resources for sustainable use. safeguarding ecosystem function and biodiversity, and/or providing a framework for supporting uses of resources and space with a minimum of conflict. MACPAs are not merely marine parks or sanctuaries, in strict definitions of the words. They range from small closed areas or harvest refugia, designated to protect a specific resource or habitat type, to extensive coastal zone areas that integrate the management of many species, habitats, and uses in a single, all-encompassing plan. A large number of MACPAs (260 subtidal sites) are located in the Australia/New Zealand region, while few (15 subtidal sites) exist in the Central Indian Ocean region (Kelleher et al., 1995). A total of 640 subtidal existing and potential MACPA sites have been identified by Kelleher et al. (1995) as priorities for global conservation of marine biodiversity. However, they also report that only 232 of these sites have officially implemented management plans.

Marine and Coastal Protected Areas can serve a great range of functions and exist in a wide array of designs. At the most basic level, MACPAs can protect marine biodiversity by protecting endangered species, critical habitats, seed banks, and sources of recruits through the establishment of nonextractive zones or harvest refugia (Agardy, 1994). On a complex level, MACPAs do much more than this to enhance the protection of marine biotic resources. Today's MACPAs range from small areas designated to maximize value to a single set of stakeholders to extensive, multiple-use areas meant to accommodate a wide variety of user groups. The common thread that should tie all MACPAs together is that the implementation of the protected area provides a concrete framework for developing, executing, or testing management measures. In essence, a MACPA allows stakeholders-whether recreationists, industry, scientific researchers, resource managers, or various governmental agencies - to identify areas as worthy of interest and protection.

Large multiple-use protected areas can be thought of as demonstrating the concept of ecosystem-based management. where the limits of protection in a geographical sense are based on the extent of movements of organisms and physically linked processes. The underlying ecology thus defines the outer boundaries for the area of protection. In recognizing these linkages, MACPA planners can work toward conserving ecosystem in- tegrity, not just individual resources or ecosystem structure. Modern MACPAs should be designed with ecological linkages in mind; the ultimate nature of the protected area reflects the specific objectives for which it was created.

The human element in MACPAs cannot be understated. Humans and their needs are the driving force for MACPA work, and humans stand most to benefit from their effective implementation. The designation of a MACPA can provide local communities, decision-makers, and other stakeholders with a defined arena in which to promote effective management. The success of any protected area is closely related to how well user groups and stakeholders are identified and brought into the planning and management processes for the protected area. MACPAs cannot afford to be elitist, nor can they be exclusionary.

Although some aspects of terrestrial conservation are applicable to marine and coastal ecosystems, these aquatic environments exhibit a number of characteristics that differ from or simply do not exist in terrestrial systems. Administrators of MACPAs are faced with very distinct management challenges compared with their terrestrial counterparts, as a result of the fundamentally different physical and biological characteristics of oceans and estuaries. There are a number of examples of marine and coastal ecosystem characteristics that do not occur in terrestrial environments. The marine environment is also more stable than the terrestrial environment, natural diurnal and annual fluctuations in environmental parameters are normally small, and the organisms adapted to the marine environment are consequently vulnerable to relatively small perturbations of the environment. In addition, the fluid environment leads to the characteristics of buoyancy (allowing for organisms that spend their entire life-cycle within the water column and never touching the "ground"), pressure (although similar in principal to the atmosphere, greatly increased magnitude), and a three dimensionality that also influences light penetration and productivity methods (a greater fraction of the sea is light limited, and distinct layers of biochemically based communities throughout the water column). Currents are much more influential on marine ecosystem dynamics than are air currents to terrestrial ecosystems, leading to filtration as a major means of obtaining energy and enormous ranges of dispersal at all life-stages. In addition, primary production in the sea is generally through phytoplankton (single-celled) as opposed to vascular plants in the terrestrial environment. Having shorter life spans and higher turnover rates, phytoplankton can respond much more quickly as a population to changes and perturbations than the primary producers that dominate terrestrial systems. The longest-lived organisms in terrestrial environments tend to be large trees. whereas in
The human element

in MACPAs cannot

be understated.

Humans and their

needs are the driving

force for MACPA

work, and humans

stand most to benefit

from their effective

implementation. 
the sea they tend to be large organisms at the highest trophic levels.

Perhaps the most important long-term role that MACPAs can play in protecting marine biodiversity is improving the public's education about marine resources and serving as a physical reminder of the benefits of natural resource protection. Because the MACPA planning process involves stakeholders and user groups, the process can be effective in instilling a sense of stewardship among users and providing a basis for sustainable management of marine resources (Agardy. 1994). Improvements in ecosystem health due to the establishment of an MACPA are a visible success and a further source of pride that can enhance ecosystem protection values within a community.

Although studies detailing the ecological impacts of MACPAs are limited, there are examples. For instance. fish populations have increased and other marine resources have improved considerably in Looe Key and Key Largo, FL, USA since the designation of these areas as National Marine Sanctuaries (Bohnsack, 1991; Causey, 1991). Protective management strategies in a short-lived MACPA in Sumilan Island, Philippines maintained high abundances of fishes in the MACPA and significantly higher yields to fisherman from areas adjacent to the MACPA (Alcala and Russ, 1990). Within 18 mo of the opening of this MACPA to fishing, significant reductions of fishes occurred (54\% decline in total yield of numerous species of reef fishes), and catch per unit effort was significantly reduced. Traps and gill nets damaged the habitat and reduced populations of nontargeted species. Species densities, biomass, and diversity were found to be significantly greater for rocky substrates within the Scandola MACPA in Corsica when compared with similar gabitats immediately adjacent to the MACPA (Francour, 1991).

In a world of rapidly changing economies, MACPAs can provide a mechanism for preserving traditional uses by local and indigenous peoples that have proved sustainable over millennia (Agardy, 1994). Indeed, the rich cultural heritage associated the use of marine resources is in decline. Historically, the development of coastal communities dependent on the marine environment took place through the development of a wide range of skills. Some individuals were hunters and fisherman who gathered the natural bounty of the marine environment through a wide variety of activities. Others were artisans who built the boats or manned the manufacturing facilities associated with the coast. Others were industrialists engaged in shipping and other marine trades. All of these provided a rich cultural diversity that is currently being lost with declining marine biodiversity, but that can be maintained through the establishment of MACPAs that seek to conserve both cultural and biological diversity.
MACPAs serve as an important testing ground for new concepts in biodiversity management strategies that attempt to refine the relationship of science and policy. One of the most significant of these ideas is "adaptive management." Adaptive ecosystem management has been defined, by the federal Ecosystem Management Task Force and Science Subcommittee of the Interagency Task Force For the Restoration of South Florida, as a structured, iterative approach for improving resource management. It accepts, a priori, that the information used in making natural resource management decisions is imperfect and that, as decisions are implemented, a structure must be in place to gain better information and adjust the implemented action accordingly. This structure consists of models, special studies, and monitoring, used as coordinated, supportive tools for improved management. For management to be both flexible and responsive to environmental and social changes, an explicit feedback loop must be maintained between science and management. To objectively test the efficacy of management regulations, management measures must provide a laboratory for experimental testing of these regulations (Agardy. 1994). The best adaptive models of ecosystem functions define a system of inputs, interactions, and outputs, where management regulations are continually adapted until the desired management outcome is realized. Because MACPAs are real entities, they are able to act as an experimental laboratory in which management adapts to both changing conditions and changing needs, and in which the necessary link between science and policy can be maintained (Agardy, 1994).

An equally important principle in the interaction of science and policy concerning marine ecosystem management and marine biodiversity conservation is the precautionary principle. By employing the precautionary principle, management of marine systems goes from reactive to proactive, from responding to damage and threats to avoiding negative impacts. Given the growth of human populations and accompanied resource demand and the limited effectiveness of international efforts to conserve global biodiversity, the presumption that the health of marine and coastal ecosystems will continue to deteriorate seems accurate. In such an environment, MACPAs provide an opportunity to apply the precautionary principle in a physical setting and protect marine and coastal resources from the dangerous threats of over exploitation. habitat destruction, and pollution.

\section{Mechanisms for Advancing MACPAs and Marine Biodiversity Protection}

There are several international, national, and state/local level mechanisms that serve to advance MACPAs as vehicles for promoting the long-term conservation and sustainable use of marine biodiversity, and these are outlined briefly below. 
Globally, the combination of these mechanisms have inacted at least 1.306 subtidal MACPAs that have a median size of 1.584 hectares (Kelleher et al., 1995). In the international sphere these include the United Nations Man and the Biosphere program, the World Conservation Union (IUCN), the Biodiversity Convention, the Regional Seas Program, and IMO Sensitive Sea Areas. The United States also supports a U.S. Man and the Biosphere Program, as well as other active MACPA programs such as the National Oceanic and Atmospheric Administration's (NOAA) National Marine Sanctuary (NMS) and National Estuarine Research Reserve System (NERRS) programs, and the Department of Interior"s various marine and coastal National Parks. NOAA"s Office of Ocean and Coastal Resource Management, which is charged with overseeing the NMS and NERRS programs, is also responsible for the National Coastal Zone Management (CZM) program. The CZM programs of states such as North Carolina, Florida, and California provide additional mechanisms (controlling nonpoint source pollution, preventing coastal habitat destruction, etc.) for marine biodiversity conservation and MACPA establishment at the local level.

\section{United Nations and U.S. Man and Biosphere Programs}

These Man and Biosphere Programs focus on the management goals of conservation, research. and sustainable development. This is accomplished by supporting both interdisciplinary, ecosystembased "core projects" dedicated to solving problems associated with the effects of human impacts, over time, on natural ecosystems, and through Biosphere Reserves (UNESCO, 1984: Dept. of State. 1990). A model Biosphere Reserve consists of a core area (minimally disturbed ecosystems), a buffer zone (zone of managed use) that adjoins or surrounds the core area and a transition area (undelimited, dynamic zone of cooperation in which conservation knowledge and management skill are applied). Biosphere Reserves are often implemented through the combination of smaller, highly protected MACPAs and larger, multiple-use management areas into Biosphere Reserves.

\section{World Conservation Union (IUCN)}

In February of 1988, the 17th General Assembly of the World Conservation Union (formally known as the International Union for the Conservation of Nature and Natural Resources-IUCN) adopted a resolution on protection of the coastal and marine environment that states as its goal "To provide for the protection, restoration, wise use. understanding and enjoyment of the marine heritage of the world in perpetuity through the creation of a global. representative system of marine protected areas. . . " The resolution further states that such a system should have the following objectives:
- To protect and manage substantial examples of marine and estuarine systems to ensure their long-term viability and to maintain genetic diversity;

- To protect depleted, threatened, rare or endangered species and populations and, in particular to preserve habitats considered critical for the survival of such species;

- To protect areas of significance to the life cycles of economically important species;

- To prevent outside activities from detrimentally affecting the marine protected areas:

- To provide for the continued welfare of people affected by the creation of marine protected areas:

- To preserve, protect. and manage historical and cultural sites and natural aesthetic values of marine and estuarine areas, for present and future generations:

- To facilitate the interpretation of marine and estuarine systems for the purposes of conservation. education. and tourism;

- To accommodate within appropriate management regimes a broad spectrum of human activities compatible with the primary goal in marine and estuarine settings;

- To provide for research and training, and for monitoring the environmental effects of human activities, including the direct and indirect effects of development and adjacent land-use practices.

\section{UNCED Convention on Biological \\ Diversity/Agenda 21}

Although the protection of marine biota is not specified in the commitments of the Biodiversity Convention (the development of in situ conservation mechanisms, the restoration of degraded ecosystems and recovery of endangered species. and the preservation of indigenous systems of biological resources management are all specified without specific reference to marine ecosystems), Chapter 17 of Agenda 21, which was adopted at the 1992 UNCED Conference, is devoted to the "Protection of Oceans, All Kinds of Seas, including Enclosed and Semi-Enclosed Seas, Coastal Areas, and the Protection, Rational Use and Development of their Living Resources." Agenda 21 does recommend the establishment and management of marine protected areas as a mechanism for conserving marine biological diversity. Chapter 17 identifies action agenda items for the protection of marine ecosystems:

- integrated management and sustainable development of coastal areas, including exclusive economic zones;

- marine pollution prevention and control;

- sustainable use and conservation of marine living resources of the high seas;

- sustainable use and conservation of marine living resources under national jurisdiction;
Agenda 21 does

recommend the

establishment and

management of

marine protected

areas as a mecha-

nism for conserving

marine biological

diversity. 
- addressing critical uncertainties for the management of the marine environment and climate change;

- strengthening international, including regional, cooperation and coordination; and

- sustainable development of small islands.

\section{UNEP Regional Seas Program}

The United Nations Environment Program (UNEP) was established in 1972 to ensure that governments adequately address significant global environmental issues, and the Regional Seas Program was designed to facilitate this in the marine environment. Regional Seas are enclosed or semienclosed seas that fall under the jurisdiction of more than one nation. Regional Seas become marine managed areas when bilateral or multilateral agreements are drawn up to control pollution, develop cooperatively managed areas (e.g., transboundary reserves), and allow for joint management of endangered species or commercially important renewable resources. The goals of the Program are to foster:

- an Action Plan for cooperation in coastal and marine resource development, pollution control, and research and monitoring;

- a convention setting forth the general commitments of the countries of the regions, and

- more specific and detailed protocols to deal with particular issues and objectives.

There are 10 Regional Seas Programs, with $>120$ participating countries in the Mediterranean; the Kuwait region of the Persian/Arabian Gulf; the Red Sea: the Eastern Africa coast; the South Asian Seas; East Asia: the South Pacific islands; the Pacific coast of South America; the wider Caribbean; and the Atlantic coast of West and Central Africa. Historically, the Regional Seas Program has been perceived by member countries as a mechanism for addressing marine ecosystems issues with little tension between North and South (Norse, 1993).

\section{IMO Sensitive Sea Areas}

The International Maritime Organization (IMO), a specialty organization of the United Nations that focuses on shipping issues such as the prevention and control of marine pollution from ships, recognizes Sensitive Sea Areas. Under the Sensitive Sea Areas Program, ship transit is prohibited for reasons of safety and environmental sensitivity in areas of ecological or socioeconomic significance (e.g., coral reefs, temperate sounds). Nonship transit uses are permitted in Sensitive Sea Areas unless there are other protection designations in place.

\section{Intergovernmental Oceanographic Commission}

The Intergovernmental Oceanographic Commission (IOC) has the special mandate ". . . to promote scientific investigations and related ocean services, with a view to learning more about the nature and resources of the ocean "(Article 1, part 2 of IOC Statutes). At its XXVII Session (Paris, July 1994), the IOC Executive Council considered marine biodiversity to be an area of particular relevance to IOC activities, given the great need for research in this subject areas. Therefore the IOC, in partnership with NOAA. called for an "ad hoc Consultation on Marine Biodiversity." which was held in Paris in May, 1995. The Consultation drew from an international field of experts. The main objective of the Consultation was to formulate a draft proposal for an IOC program on marine biodiversity.

The general recommendation of the Consultation was that IOC should reevaluate its existing programs and activities with a view of enhancing marine biodiversity as an IOC activity. Because of the close relationship between habitat destruction and biodiversity reduction, the Consultation specifically recommended that national inventories and monitoring of the quantitative extent and qualitative condition of typical habitats (coral reefs, mangrove areas, salt marshes, etc.) be emphasized. They further recommended that a global network of representative ecosystems be established for pilot projects for integration of baseline inventories, research activities, community level education, low-technology methods for monitoring, and comprehensive management for sustainable use and conservation of marine biodiversity.

\section{U.S. National Marine Sanctuaries Program}

The National Marine Sanctuaries (NMS) Program was established by the Marine Protection, Research. and Sanctuaries Act (MPRSA) of 1972 to designate and manage nationally significant marine and Great Lakes areas. The Program is administered by NOAA with its Office of Ocean and Coastal Resource Management (OCRM) being responsible for managing all of the NMS sites. Through research and education, the NMS Program seeks to increase the scientific understanding of our marine resources. The highest priority for all NMS is the long-term protection of resources. The NMS Program emphasizes the sustainability of the oceans. However, continued use of the oceans is possible only if their overall health and resilience is maintained. The NMS Program provides for multiple uses within Sanctuaries, as long as they are balanced with measures to maintain the health and integrity of these ecosystems. Since 1972, 13 Sanctuaries have been designated and currently protect more than $4.3 \times 10^{+} \mathrm{km}^{2}$ of ocean. The locations of the current NMS sites (Fig. 1) represent a number of distinct marine environments including near-shore, open water, and benthic ecosystems, in temperate and tropical areas. The NMS sites vary greatly in size and proximity to coastal areas. Fagatele Bay Sanctuary in American Samoa is $9.6 \times 10^{-1} \mathrm{~km}^{2}$, whereas the Florida 


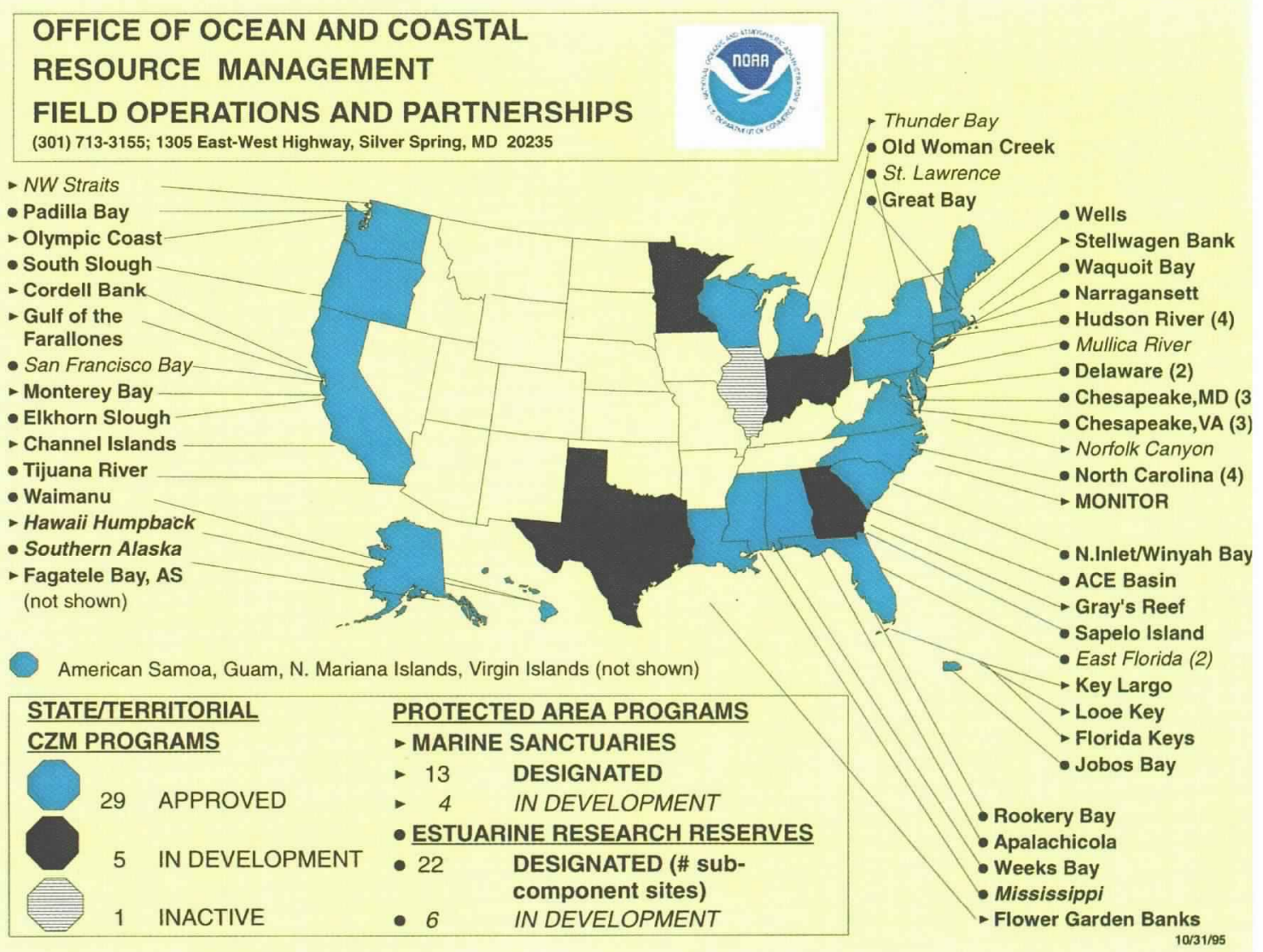

Figure 1: Status of National Marine Sanctuary and National Estuarine Research Reserve Systems sites, and Coastal Zone Management programs throughout the United States as of 1995.

Keys Sanctuary and the Monterey Bay Sanctuary are $9.6 \times 10^{3}$ and $1.4 \times 10^{4} \mathrm{~km}^{2}$, respectively.

For a site to be considered for a NMS, it must be judged to be of special national significance. National significance is based on conservational, ecological, aesthetic, recreational, historical, research, and/or educational value of the site. The site may then be selected as an NMS, based on numerous factors such as available staff and resources, biogeographic and resource representation, and relative costs and benefits of designation. The final designation process includes the preparation of an Environmental Impact Statement/Management Plan, consultation with governmental bodies, and public meetings. The Looe Key and Key Largo NMS are examples of the positive impacts of the NMS Program on biodiversity (Bohnsack, 1991; Causey, 1991).

\section{U.S. National Estuarine Research Reserve System}

Section 315 of the Coastal Zone Management Act of 1972, 16 U.S.C. 1461, establishes the National Estuarine Research Reserve System (NERRS) to provide financial assistance awards to acquire, develop, and operate estuarine areas in the United States as natural field laboratories. These areas are used primarily for long-term scientific and educational programs that provide information essential to coastal management decision making. The NERRS Program is administere by OCRM, NOAA.

The NERRS consists of carefully selected estuarine areas of the United States that are designated, preserved, and managed for research and educational purposes. The Reserves are chosen to reflect regional differences and to include a variety of ecosystem types in accordance with the biogeographic classification scheme of the national program. Each NERRS site is uniquely suited for supporting a wide range of beneficial uses of ecological, economic, recreational, and aesthetic values that are dependent on maintenance of a healthy ecosystem. Each site provides critical habitat for a wide range of ecologically and commercially important species of fish, shellfish, birds, and other aquatic and terrestrial wildlife. Each Reserve has been designated to ensure its effectiveness as a conservation unit and as a site for longterm research and monitoring. The NERRS has a long history of conducting management-related research pertaining to conservation and sustainable use of marine and coastal biodiversity (Crosby, 1994b; Crosby and Golde, 1993; Crosby and Beck, 1995). As part of a national system, the Reserves collectively provide a unique opportunity to address estuarine biodiversity research questions and management issues of national significance,
As part of a na-

tional system, the

Reserves collectively

provide a unique

opportunity to

address estuarine

biodiversity research

questions and

management issues

of national

significance, . . . 
such as impacts of nonpoint source pollution. land-use practices, and introductions of nonindigenous species to coastal biodiversity. As of September, 1995. 22 NERRS sites have been designated (Fig. 1) and encompasses over $1.7 \times 10^{5}$ hectares of coastal habitat.

\section{U.S. National Park Service}

The mission of the National Park Service (NPS) is to preserve historical, natural, and recreational areas of national significance. This mission is accomplished by limiting the types of use permitted in parks, and in some areas by limiting access. The NPS system includes $>360$ sites falling into $>20$ different designations categories (e.g., National Historic Monument; National Seashore). Although there is an extensive terrestrial system. marine and coastal areas are set aside in the NPS system along the entire length of the East and West Coasts, along areas of the Gulf Coast, in the Pacific and Atlantic U.S. territories, and within the Great Lakes system. These areas are a mix of $\mathrm{Na}$ tional Parks (NP) such as the Everglades NP in Florida, Voyageurs NP in Minnesota, and the Virgin Islands NP in the Atlantic Ocean and National Seashores (NS) such as Point Reyes NS in California, Gulf Islands NS in Alabama, Cape Lookout NS in North Carolina, and Cape Cod NS in Massachusetts. Several of the areas in the National Park system are also designated as Biosphere Reserves and/or World Heritage Sites. The marine National Parks and National Seashores are a disproportional large percentage of these internationally recognized sites.

\section{U.S. State Programs}

The primary mechanism for states to establish MACPAs is via the cooperative federal-state NERRS previously described, and most of the states that participate in the voluntary U.S. CZM program (Fig. 1) have taken advantage of the opportunity provided by NERRS. In addition. many coastal states have used CZM program funds and legislation to establish other types of protected areas. North Carolina, for example, has used CZM funding to purchase 337 acres of Buxton Woods on Hatteras Island. one of the last large areas of intact Atlantic maritime forest. Funding under the CZM has allowed Florida's Aquatic Preserve Program to develop management plans for many of the state aquatic preserves. and Florida also has additional statutory mechanism for the development of MACPAs. Chapter 258 of the state coastal manage ment legislation gives the Department of Natural Resources (DNR) authority to establish state parks and preserves, and Chapter 259 gives Florida's DNR the authority to acquire land for conservation and recreation. In an effort to protect diminishing wetlands, California used CZM funding to purchase Rush Ranch in Suisan Marsh, and under the federal consistency re- quirement of the federal CZM, California was able to negotiate an agreement with the Air Force to permanently preserve 135 acres of land at White Point, creating the White Point Park, an important coastal urban park.

\section{Challenges for the Future}

The important role of protected areas in the maintenance of biological diversity is recognized in major international instruments including the Convention on Biological Diversity (notably Article 8), Chapter 17 of Agenda 21 from the UN Conference on Environment and Development. and the IOC-NOAA ad hoc Consultation on Marine Biodiversity. The IOC-NOAA Consultation acknowledged that the worldwide destruction of marine and coastal habitats is the greatest threat to marine biodiversity. The IOC-NOAA expert group considered, however, that anthropogenic effects on biodiversity often cannot be clearly distinguished from natural variability in species. populations, and ecosystems. Long-term monitoring of the diversity of biological communities and ecosystems is needed, but there is at present no generally recommended sampling design or parameters for monitoring (indices of diversity, species distribution models. indicator species. etc.). The IOC-NOAA expert consultation therefore recommended that IOC provide advice to Member States for selection of parameters and development of "low-tech" methodologies for monitoring changes in marine biodiversity and ecosystem condition. Similar calls for monitoring changes in biodiversity through the utilization of networks of marine and coastal sites have also come from the U.S. Coral Reef Initiative (Crosby et al.. 1995; Crosby and Maragos, 1995) and the United States effort to control nonindigenous species (Crosby, 1994b; Bjergo et al., 1995). Particular efforts should be made to establish methodologies for rapid assessments that do not require the existence of a set of taxonomic experts. A standardized set of parameters and methodologies would also be useful for comparative analyses and for estimates of changes in biodiversity in a global context.

A growing number of MACPA managers and scientists have been attempting to define a new paradigm for better identification, selection, and management of MACPAs around the world. The concept of MACPAs has developed and evolved to the point where there is a need to develop new methodologies for selecting and integrating MACPAs into the management of national and international coastal and marine systems. The International Group of Experts on MACPAs was formed to set a process in motion for redefining and implementing the role of MACPAs in resource stewardship. Members of the group come from the United States. Canada, Australia, United Kingdom. Ireland, Tanzania, People's Republic of 
China. Mexico, the Bahamas, New Zealand and UNESCO, and include government officials, academics and representatives of nongovernment organizations.

The first meeting in Canberra, Australia, in August 1994, was entitled "Marine Protected Areas and Biosphere Reserves: Towards a New Paradigm." It focused mainly on management and developed a set of key principals. It also gave emphasis to the UNESCO Biosphere Reserve concept. The second meeting, in Tampa in July 1995 was entitled "Second International Symposium and Workshop on Marine and Coastal Protected Areas," and focused on selection of MACPAs to complete national and global networks. As a result of these first two symposia and workshops, the International Expert Group on MACPAs have agreed that MACPAs:

- have a critical role in the management for longterm conservation and sustainable use of marine and coastal biological diversity:

- lunction as focal points for development of governance for coastal and ocean systems; and

- provide for local community education and training in the importance of conserving marine and coastal biodiversity.

The Group concluded with two principal recommendations for the various national and international MACPA programs:

- The marine environment, especially in coastal areas. is integrally linked to the terrestrial environment. Accordingly. management of the marine environment must account for impacts from the coastal zone. Successful management of MACPAs for long-term conservation and sustainable use of biological diversity can only occur if it is integrated with broader coastal zone management.

- The need exists for a systematic approach to the selection of biogeographically representative sites and development of an integrated network of MACPAs that maintains and enhances the links between sites. The approach should be developed with a global perspective, taking account of the different local, national, and regional needs and opportunities in different areas. This needs to be coordinated internationally and, as far as practicable. applied consistently.

It is easy to have a robust set of mechanisms for the establishment of MACPAs on paper or in concept, as many of the programs described in the previous section do. What on paper may look like a fully functional, integrated, and meaningful system, however, is quite often not very well integrated into national and international marine and coastal governance and resource management. The establishment of many of the described mechanisms and programs are too often the result of the hard work of a few focused individuals who have identified the opportunities in marine biodiversity protection that MACPAs can address. MACPAs are still viewed by many people and governments as areas set aside for an elitist user group (Agardy, 1994). Similarly, the enormous cultural, socioeconomic and ecological benefits of MACPAs are often only realized after years of existence and sometimes difficult to study and quantify. Thus building the prerequisite political support for many of these MACPA programs can be difficult to garner. There is a critical need for interdisciplinary studies to examine not only the biological diversity and ecological, but also the cultural and socioeconomic. impacts of various MACPA management strategies (Crosby. 1994a).

In truth, no internationally coherent system of marine governance exists that is capable of providing the context for management of human activities in the marine and coastal environment that will truly provide for long-term conservation and sustainable use of the biome's marine biodiversity. Within the United States alone, governance of marine resources is characterized by a number of different problems, including multiagency jurisdictions, funding restrictions, and limited patience to await the results of biodiversity management mechanisms. Failure to meet the challenges posed by these bureaucratic and political problems means that significant values and opportunities associated with the marine environment are being lost or pursued only ineffectively. Fragmented management often results in the mismanagement of many marine biodiversity issues and failure to resolve conflicts. Current management of the U.S. marine environment is carried out at the local. state. regional, and national levels of government. In addition, at any given level of government. various functions can be carried out through a wide array of agencies and organizations with little or no coordination among them. Although the ability to establish MACPAs is part of only a few focused national programs, many more programs and agencies have mandates to manage marine resources. Funding resources are being regressively spread thinner among and within these agencies, and this has severely limited the ability of systems of MACPAs, such as the National Marine Sanctuaries Program and the National Estuarine Research Reserve System to manage for long-term conservation and sustainable use of marine and coastal biodiversity resources at risk in many biogeographic provinces and habitats.

This fragmentation can also mean that significant marine biodiversity issues receive inadequate attention. Thus, although a number of agencies purport to exercise some responsibilities for management of marine and coastal habitats, when viewed from a national or global perspective, habitat issues critical to long-term conservation and sustainable use of marine biodiversity are simply

\section{Successful manage-}

ment of MACPAs for

long-term conserva-

tion and sustainable

use of biological

diversity can only

occur if it is inte-

grated with broader

coastal zone man-

agement. 
not addressed. Fragmentation also means that real or potential conflicts either between governmental requirements or proposed uses are often not identified a priori, and when problems emerge. there are few effective means for resolving them. The challenge now facing marine conservation biology is to work in partnership with government to limit fragmentation of responsibilities among agencies and to tie together the ends of a loose system of MACPAs in order to create a true and robust system for protecting marine biological diversity.

\section{References}

Agardy, M.T., 1994: Advances in marine conservation: the role of marine protected areas. Trends Ecol. Evol., 9, 267-270.

Alcala, A.C. and G.R. Russ, 1990: A direct test for the effects of protective management on abundance and yield of tropical marine resources. J. Cons. Int. Explor. Mer. 46. $40-47$

Bjergo, C.. C. Boyden. M.P. Crosby. S. Kokkanakis and R. Sayers, 1995: Non-native aquatic species in the United States and coastal waters. In: Our Living Resources-A Report to the Nation on the Distribution, Abundance, and Health of U.S. Plants, Animals, and Ecosvstems. E.T. LaRoe, G.S. Farris, C.E. Puckett. P.D. Doran and M.J. Mac. eds.. U.S. Dept. Interior-National Biological Service. Washington, DC, 428-431.

Bohnsack. J.A., 1991: Marine fishery reserves for reef fishes: lessons from Key Largo and the Looe Key National Marine Sanctuary. Proceedings of the American Fisheries Society. San Antonio, TX, 128.

Causey, B.D., 1991: Harvest refugia and marine sanctuaries: evidence from Looe Key national Marine Sanctuary. Proceedings of the American Fisheries Society, San Antonio, TX. 129.

Crosby, M.P., 1994a: A proposed approach for studying ecological and socio-economic impacts of alternative access management strategies in marine protected areas. In: Marine Protected Areas and Biosphere Reserves: 'Tow'ards a New Paradigm'. D.J. Brunkhorst, ed., Australian Nature Conservation Agency. Canberra, Australia, 45-65.

1994b: Opportunities for nonindigenous species research and monitoring in NOAA's National Estuarine Research Reserves. In: Nonindigenous Estuarine and Marine Organism Conference, Seattle, WA. Proceedings of the Conference and Workshop, April, 1993. National Oceanic and Atmospheric Administration, Washington, DC, 69-78.

and A.D. Beck, 1995: Management-oriented research in National Estuarine Research Reserves, with examples of fisheries-focused studies. Nat. Areas J. 15, 12-20.

S.F. Drake, C.M. Eakin, N.B. Fanning, A. Paterson, P.R. Taylor and J. Wilson, 1995: The United States Coral Reef Initiative: an overview of the first steps.
Coral Reefs, 13, 249-251.

and H.M. Golde, 1993: A Review and Synthesis of the First Decade of Research in the National Estuarine Research Reserve System. Technical Memorandum \#26. Office of Ocean and Coastal Resource Management. National Ocean Service, National Oceanic and Atmospheric Administration. Washington, DC.

and J.E. Maragos. 1995: The United States Coral Reef Initiative. In: Marine and Coastal Biodiversity in the Tropical lsland Pacific Region. vol. I: Species Systematics and Information Management Priorities. J.E. Maragos. M.N.A. Peterson, L.G. Eldredge, J.E. Bardach, and H.F. Takeuchi. eds.. East West Center, Honolulu, HI, 303-316.

Culliton, T.J., M.A. Warren, T.R. Goodspeed, D.G. Remer. C.M. Blackwell and J.J. McDonough, III, 1990; The Second Report of a Coastal Trends Series: 50 Years of Population Change along the Nation's Coasts, 1960-2010. National Oceanic and Atmospheric Administration, Rockville, MD, $41 \mathrm{pp}$.

Davis, R.A., Jr., 1973: Principles of Oceanography. AddisonWesley, London, $434 \mathrm{pp}$.

Department of State, 1990: The United States Man and the Biosphere Program. Bureau of Oceans and International Environmental Science and Technology. Department of State Publications, Washington, DC, 24 pp.

Francour. P. 1991: The effects of protection level on a coastal fish community at Scardolia. Corsica. Rev. Ecol., 46, 65-81.

Grassle, J.F. and N.J. Maciolek. 1992. Deep-sea species richness: regional and local diversity estimates from quantitative bottom samples. Amer. Nat., 139, 313-341.

Kelleher, G.C. Bleakley and S. Wells, 1995: A global Representative System of Marine Protected Areas. vol. I, 219 pp.

NOAA, 1995: Florida Keys National Marine Sanctuary Draft Management Plan/Environmental Impact Statement. Vol. I-III. National Oceanic and Atmospheric Administration, Silver Spring, MD, $568 \mathrm{pp}$.

Norse. E.A., ed., 1993: Global Marine Biological Diversity: A Strategy for Building Conservation Into Decision Making. Island Press, Washington, DC, $383 \mathrm{pp}$.

Odum, H.T., B.J. Copeland and E.A. McMahan, eds., 1976: Coastal Ecological Systems of the United States, Vol. I, II. III, IV. The Conservation Foundation, Washington, DC

Ray. G.C. and M.G. McCormick-Ray, 1990: A Future for Marine Sanctuaries, Report to NMS Review Panel.

Sobel, J., 1993: Conserving biological diversity through marine protected areas: a global challenge, Oceanus, 36. 19-26.

Solbrig. O. 1991: From Genes to Ecosystems: A Research Agenda for Biodiversity. International Union of Biological Sciences (IUBS), Paris. $124 \mathrm{pp}$.

Thomson. K.S., 1991: Living Fossil: the Story of the Coelacanth. W.W. Norton, New York.

Tunnicliffe, V., 1991: The biology of hydrothermal vents: ecology and evolution. Oceanogr. Mar. Biol. Annu. Rev., 29, 319-407.

United Nations Educational, Scientific and Cultural Organization. 1984: Action Plan for Biosphere Reserves. In: $\mathrm{Na}$ ture and Resources. vol. 20, 4, UNESCO. Paris, $12 \mathrm{pp}$.

Weber, M.L. and J.A. Gradwohl, 1995: The Wealth of Oceans Norton. New York, 256 pp. 